\title{
Response to chemotherapy with benznidazole of clones isolated from the 21SF strain of Trypanosoma cruzi (biodeme Type II, Trypanosoma cruzi II)
}

\author{
Resposta à quimioterapia com benzonidazol de clones isolados da cepa \\ 21SF do Trypanosoma cruzi ( biodema Tipo II, Trypanosoma cruzi II)
}

\author{
Rozália Figueira Campos $^{1,2}$, Marcos Lázaro S. Guerreiro ${ }^{1,2}$, Karina de Souza Castro Sobral ${ }^{1}$, \\ Rita de Cássia P. Cunha Lima ${ }^{1}$ and Sonia G. Andrade ${ }^{1}$
}

\begin{abstract}
Susceptibility to chemotherapy with benznidazole was investigated of 5 clones isolated from the $21 \mathrm{SF}$ strain (biodeme type II, Trypanosoma cruzi II). Swiss mice were infected with the parental strain for each clone and submitted to chemotherapy with benznidazole ( $100 \mathrm{mg} / \mathrm{kg} /$ day during 90 days). Treatment determined negativity of the parasitemia. Cure rates were evaluated by parasitological cure tests. Serology was evaluated for treated animals (titers from negative to 1:640) and untreated controls (1:160 to 1:640). Cure rates varied from 30 to $100 \%$ for the 5 clones, and were $25 \%$ for the parental strain. Results suggested that the variability of response to treatment of the clonal populations of Trypanosoma cruzi II strains is responsible for the high variation in the response to chemotherapy with benznidazole and nifurtimox by strains of this biodeme.
\end{abstract}

Key-words: Trypanosoma cruzi. Trypanosoma cruzi II. Biodeme Type II. Clones. Benznidazole. Chemotherapy.

\section{RESUMO}

A suscetibilidade à quimioterapia com o benzonidazol, de 5 clones isolados da cepa 21SF (biodema Tipo II, T. cruzi II), foi investigada. Camundongos suíços foram infectados com a cepa parental e com cada clone e submetidos à quimioterapia com benzonidazol (100mg/k/dia durante 90 dias). Os índices de cura foram avaliados pelos testes de cura parasitológicos. A sorologia foi avaliada para os animais tratados e (de negativo a 1: 640) e para os controles não tratados( 1:160 a 1:640). Os índices de cura variaram de 30\% a 100\% para os 5 clones sendo de 25\% para a cepa parental. Os resultados sugerem que a variabilidade de resposta ao tratamento das populações clonais das cepas Trypanosoma cruzi II é responsável pela grande variação na resposta à quimioterapia com benzonidazol e nifurtimox das cepas deste biodema.

Palavras-chaves: Trypanosoma cruzi. Trypanosoma cruzi II. Biodema Tipo II. Clones. Benzonidazol. Quimioterapia.

Strains of Trypanosoma cruzi characterized as different Types or biodemes ${ }^{13}$ have exhibited well-marked differences in their response to chemotherapy, either with nifurtimox or benznidazole ${ }^{2}$. A variability in the susceptibility between the strains of biodeme Type II has also been observed ${ }^{2}$ and, considering the mean cure rates obtained by the evaluation of 15 strains of the referred biodeme, they were classified as presenting medium to high susceptibility. A wide individual variability of the cure rates between them has been detected. These results differ from those obtained for the biodeme Type I strains (Z2b), thatshowed high susceptibility and for the biodeme Type III strains (T. cruzi I), with a high degree of resistance ${ }^{2}$.

In the presentstudy we aimed to investigate the susceptibility of clones obtained from the $21 \mathrm{SF}$ strain, classified as biodeme Type II ( T. cruzi II). Biological and isoenzymic characters of the isolated clones reproduced the patterns of the parental strain? Molecular characterization of the clones isolated from the 21SF strain has been performed by the restriction fragment length polymorphism (RFLP) of the $\mathrm{kDNA}^{8}$. A high percentage of genetic similarity has been demonstrated for the parental strain and its

1. Laboratório de Chagas Experimental, Autoimunidade e Imunidade Celular do Centro de Pesquisas Gonçalo Moniz da Fundação Oswaldo Cruz, Salvador, BA. 2. Departamento de Ciências Biológicas da Universidade Estadual de Feira de Santana, Feira de Santana, BA, Brasil.

Address to: Dra Sonia G. Andrade. Centro de Pesquisas Gonçalo Moniz/FIOCRUZ. R. Waldemar Falcão 121, Brotas, 40295-001 Salvador, BA, Brasil.

e-mail: sgandrade@ cpqgm.fiocruz.br

Recebido para publicação em 7/5/2004

Aceito em 30/12/2004 
clones ( 67 to 100\%, for restriction endonuclease Rsa I and 83 to $100 \%$ for Hinf I), although a low degree of divergence has been observed. Considering the above results, it is important to investigate the responses to chemo therapy of clonal populations of the 21SF strain, to clarify whether the variable response to chemo therapy, already demonstrated between the various strains classified as biodeme Type II, corresponds to differences in the susceptibility of its clones. Itis important to investigate if there is any relation between resistance to chemotherapy and clonal constitution, taking into account not only the similarities observed, but also the dissimilarities that have been detected in some clones8.

\section{MATERIAL AND METHODS}

Trypanosoma cruzi strain and clones. The $21 \mathrm{SF}$ strain of T. cruzi was isolated from a patient in the acute phase of Chagas' disease, from São Felipe, Bahia State and classified as biodeme Type II, by Rocha Filho ${ }^{15}$.

Five clones of this strain, previously obtained by micromanipulation and isolation investigation. These clones were identified as 21SF-C1, 21SF-C2, 21SF-C3, 21SF-C4 and 21SF-C5 and were characterized according to the biological and isoenzymic characteristics ${ }^{7}$ and also submitted to molecular characterization ${ }^{8}$.

Percentiles of similarity resulting from the analysis of the RFLP of the several schizodemes obtained from the parental strain and its clones ${ }^{8}$ are shown in Table 1.

Table 1 - Percent of similarity from RFLPanalysis of clones of the 21SFstrain*.

\begin{tabular}{lrr}
\hline Clones & \multicolumn{2}{c}{ 21SF- P } \\
\cline { 2 - 3 } & Rsa I & Hinf I \\
\hline 21 SF- C1 & 85 & 87 \\
$21 S F-C 2$ & 93 & 83 \\
$21 S F-C 3$ & 100 & 92 \\
$21 S F-C 4$ & 82 & 100 \\
$21 S F-C 5$ & 67 & 85 \\
\hline
\end{tabular}

*In: Campos et al. Mem. Inst. Oswaldo Cruz 94: 23-29, 1999.

21SF- $\mathrm{P}=$ 21SF parental strain

Experimental groups. For the present investigation, six experimental groups of 40 swiss mice weighing 15 to $20 \mathrm{~g}$ were used. Each group was inoculated with $5 \times 10^{4}$ trypomastigotes obtained from the blood of mice infected with the parental strain and each clone, respectively. Parasitemia of the infected mice was evaluated daily during the acute phase, from the $7^{\text {th }}$ day post-infection.

Treatment with benznidazole. From each experimental group, 30 mice were submitted to treatment with benznidazole and 10 mice were maintained untreated as controls. Treatment was initiated on the $14^{\text {th }}$ day of infection for all the clones and the parental strain. Benznidazole was administered orally, by gavage, at the doses of $100 \mathrm{mg} / \mathrm{kg}$ body weight/day; five doses were administered per week, during 90 days. Parasitemia of the treated and untreated groups were evaluated weekly. Means of parasitemia were expressed by evaluation in 5 animals of group.
Mortality: the cumulative mortality was evaluated from the initial day of treatment until 30 days after the end of treatment, when the cure tests were performed. Animals surviving at the end of experiment were sacrificed by exsanguination after anesthesia, and blood was collected for subinoculation, serology and hemoculture.

Cure rates were evaluated through the direct study of parasites in peripheral blood and by cure tests: hemoculture, subinoculation of the blood into newborn mice and xenodiagnosis.

Hemoculture: $0.5 \mathrm{ml}$ of blood from the treated mice was cultivated using Warren medium: Hemoculture examination was done on 10, 20, 30 and 45 days after day 1.

Subinoculation was performed by intraperitoneal injection of $0.2 \mathrm{ml}$ of blood from each treated mouse in 5 newborn mice and tests of parasitemia in these animals from the $12^{\text {th }}$ to the $20^{\text {th }}$ day after inoculation. Xenodiagnosis was done using five $1^{\text {st }}$ stage nymphs of Dipetalogaster maximus, and examined on the $30^{\text {th }}$ and $60^{\text {th }}$ days.

Serology. Titers of specific anti-Trypanosoma cruzi antibodies in the serum collected from each mouse, treated and untreated, were evaluated by indirect immunofluorescence test, using as antigens culture forms of the parasite and goat anti-mouse fluoresceinated IgG for the secondary antibody.

\section{RESULTS}

Parasitemia. Figure 1 shows the parasitemic curves obtained from mice infected with the 21SF-P ( parental strain) and the clones 21SF- $\mathrm{Cl}$ and 21SF-C5, ( treated and untreated controls). The other clones showed irregular profiles with parasitemic peaks from 14 to 24 days post-infection, characteristics of biodeme Type II. Treatment has determined progressive decrease in the parasitemia, with negativation by direct examination of the peripheral blood, from the $20^{\text {th }}$ day after initiation of treatment.

Mortality. Table 2 shows the mortality, evaluated between the $90^{\text {th }}$ to the $120^{\text {th }}$ day after the end of treatment, for treated and untreated animals in the various experimental groups. Mortality varied from 30 to $66 \%$ in the treated groups and from 60 to $90 \%$ in the untreated controls.

Cure tests. Results of the parasitological cure tests are expressed in Table 3. Mice infected with the parental strain (21SF-P) showed a 25\% parasitological cure. Mice infected

Table 2 - Mortality of mice infected with the 21SF strain of Trypanosoma cruzi and 5 clones ${ }^{\mathrm{a}}$.

\begin{tabular}{lcc}
\hline & \multicolumn{2}{c}{ Mortality } \\
\cline { 2 - 3 } Experimental groups & treated (\%) & untreated (\%) \\
\hline 21SF- P & 66.0 & 90.0 \\
21SF- C1 & 43.0 & 80.0 \\
21SF- C & 50.0 & 80.0 \\
21SF- C3 & 30.0 & 60.0 \\
21SF- C4 & 43.0 & 70.0 \\
21SF- C5 & 40.0 & 80.0 \\
\hline
\end{tabular}

${ }^{a}$ Untreated and treated with benznidazole. 


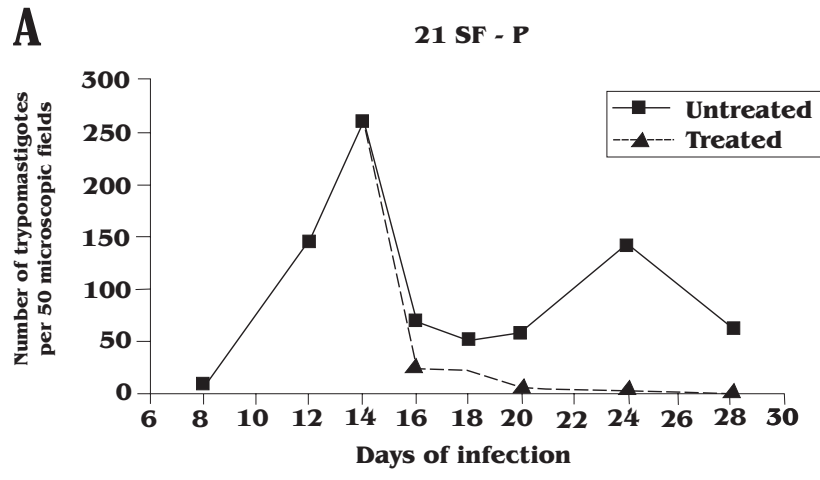

Clone 21SF - C1
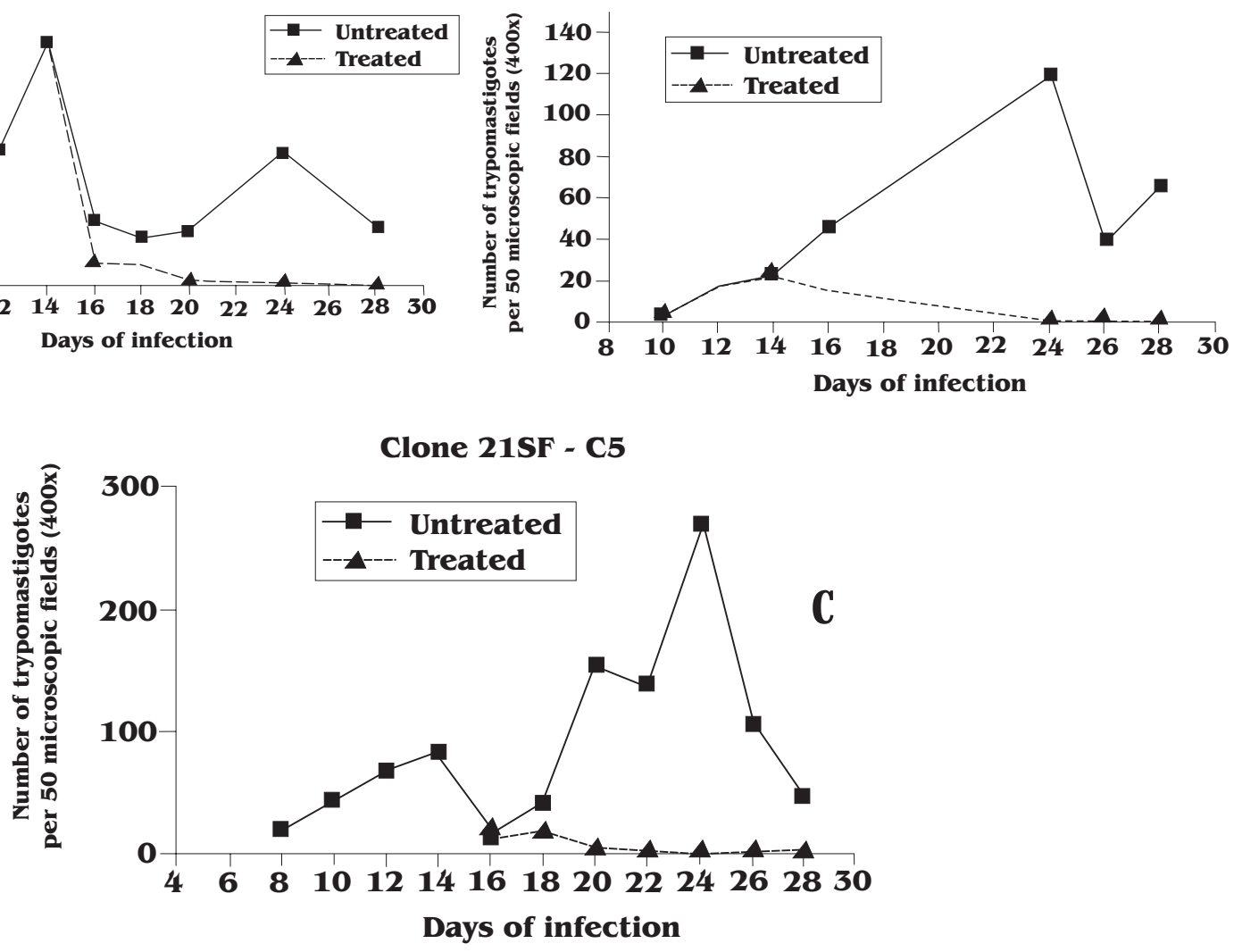

Figure 1 - Parasitemic profiles corresponding to: A - the parental strain (21SF-P); B - clone 21SF- C1, highly susceptible to chemotherapy, and C - clone 21SF-C5 with low susceptibility to treatment, showing the profiles in the untreated controls in comparison with the mice treated with benznidazole. Either the parental strain and clones 21SF- C1 and 21SF-C5, showed negativation of direct parasitemia from the $5^{\text {th }}$ day of treatment.

Table 3 - Cure rates in mice infected with Trypanosoma cruzi (21SF strain and 5 clones) treated with benznidazole, based on parasitological tests.

\begin{tabular}{lccccc}
\hline Identification & Inocula & Mice \# & $\begin{array}{c}\text { Positive } \\
\text { cases }\end{array}$ & $\begin{array}{c}\text { Parasitological } \\
\text { tests }(\%)\end{array}$ & $\begin{array}{c}\text { Cure } \\
\text { rates } \underline{\text { a }}(\%)\end{array}$ \\
\hline $21 \mathrm{SF}-\mathrm{P}$ & $5 \times 10^{4}$ & 08 & 6 & 75.0 & 25.0 \\
$21 \mathrm{SF}-\mathrm{Cl}$ & $5 \times 10^{4}$ & 17 & 6 & 35.0 & 65.0 \\
$21 \mathrm{SF}-\mathrm{C2}$ & $5 \times 10^{4}$ & 15 & 6 & 40.0 & 60.0 \\
$21 \mathrm{SF}-\mathrm{C3}$ & $5 \times 10^{4}$ & 17 & 0 & 0.0 & 100.0 \\
$21 \mathrm{SF}-\mathrm{CA}$ & $5 \times 10^{4}$ & 12 & 0 & 0.0 & 100.0 \\
21SF- C5 & $5 \times 10^{4}$ & 10 & 7 & 70.0 & 30.0 \\
\hline Total & & 79 & 25 & &
\end{tabular}

a: Combined data of parasitological ( directed blood examination, subinoculation into newborn mice, xenodiagnosis) results.

21SF- $\mathrm{P}=$ 21SF parental strain

Table 4 - Serological titers in mice infected with 21SF strain and clones, submitted to chemotherapy*.

\begin{tabular}{lcccc}
\hline & $\begin{array}{c}\text { Antibody titers } \\
\text { Untreated controls }\end{array}$ & \multicolumn{3}{c}{ Treated mice } \\
\hline Identification & $1: 320$ to $1: 640$ & $1: 80$ & to & $1: 640$ \\
21 SF - P & $1: 160$ to $1: 320$ & Neg & to & $1: 160$ \\
$21 S F-C 1$ & $1: 320$ to $1: 640$ & Neg & to & $1: 80$ \\
$21 S F-C 2$ & $1: 320$ to $1: 640$ & Neg & to & $1: 20$ \\
$21 S F-C 3$ & $1: 320$ to $1: 640$ & $1: 40$ & to & $1: 160$ \\
$21 S F-C 4$ & $1: 320$ to $1: 640$ & $1: 80$ & to & $1: 640$
\end{tabular}

* Treated with benznidazole and untreated controls

21SF - P = 21SF parental strain with the various clones presented cure rates that varied from 30 to $100 \%$. Clone $21 \mathrm{SF}-\mathrm{C} 5$ presented the lowest cure rates (30\%), similar to that obtained for the parental strain (25\%).

Serology. Serological tests revealed a variation in the titers of anti-T. cruzi antibodies in the different groups as shown in Table 4. The highest titers for treated mice were observed in those infected either with the 21SF-P ( parental strain) or with clone 21SF-C5 (1:80 to 1:640). Titers for treated mice infected with clones 21SF- C1, C2, C3, C4 varied from negative to 1:160. Untreated controls showed titers from 1:160 to 1:640.

\section{DISCUSSION}

The data obtained in the present study revealed a variability of responses to chemotherapy of the 5 clones obtained from the $21 \mathrm{SF}$ strain of T. cruzi. These data mimic the behavior registered for 15 strains of biodeme Type II, isolated from different geographical areas (including São Felipe - Bahia State); strains of São Felipe present cure rates of 28.5 to $100 \%$ of the infected and treated mice, similar to those obtained with the clones, as shown in the present study.

Investigations into the clonal constitution of the 21SF strain ( biodeme Type II), in previous studies by Campos \& Andrade ${ }^{7}$, have shown a homology between the isolated clones. It has 
been demonstrated that the profiles for the isoenzymes ${ }^{5}$ phosphoglucomutase (PGM), glucose phosphate isomerase (GPI), alanine aminotransferase (ALAT) and aspartate aminotransferase (ASAT), expressed the zymodeme Z2 ${ }^{11}$, that corresponds to the biodeme Type II, suggesting the predominance of a principal clone in this strain. The differences in response to chemotherapy between the various clones of the $21 \mathrm{SF}$ strain, could be responsible for the behavior of the parental strain that, in the present study, showed a $25 \%$ cure rate, despite presenting highly susceptible clones in its composition.

Clones resistant to benznidazole have been obtained by Murta $\&$ Romanha ${ }^{13}$ from the Y strain, based on the selection of naturally occurring resistance to benznidazole. Clones submitted to treatment with one single high dose of benznidazole for 9,12 or 25 passages in mice, became highly resistant as compared with the $Y$ wild strain that was very sensitive. The authors suggest that the resistance of $T$. cruzi strains seems to be related to the sensitive/resistant clone ratio in the population. In a previous study by our laboratory ${ }^{10}$, an attempt was made to select, by prolonged treatment, populations resistant to benznidazole and to investigate their isoenzymic characteristics, as compared with the original strain. With this objective, prototypes of the three different biodemes (Peruvian, Type I; 21SF, Type II and Colombian, Type III) were tested. No differences in the isoenzymic patterns of populations isolated from treated and untreated mice could be detected, which indicates absence of clonal selection or genetic marker alterations in the isoenzymic profiles ${ }^{10}$.

Differences in the responses to chemotherapy with nifurtimox or benznidazole, between genetically characterized clonal isolates was demonstrated by Toledo et $\mathrm{al}^{17}$, in infected Balb/c mice, with high resistance of clones 19 and 20 (Group I - T. cruzi I) in comparison with clones 32 and 39 (Group II - T. cruzi II) that were partially resistant to both drugs.

Furthermore, the susceptibility of clonal populations Z2 $\mathrm{b}^{12}$, described as biodeme Type I by Andrade et al ${ }^{5}$, has been tested by Toledo et $\mathrm{al}^{17}$, confirming its high susceptibility. In addition, these authors detected a variability of response in the resistance to chemotherapy, of isolates from T. cruzi II classified into two different genotypes ( 32 and 39). Considering its response to chemotherapy, genotype 39 isolates presented a dual pattern of response, being either partially resistantor susceptible. According to these authors, this dual behavior has also been observed among other biological properties of stocks of genotype $39^{17}$. These results confirmed the association between phylogenetic diversity with biological characters ${ }^{915}$ and chemotherapeutic responses ${ }^{234}$.

The percentile of clonal similarity, as defined by Solari et al ${ }^{16}$ by comparing restriction fragment length polymorphism (RFLP) of the 330bp fragment of variable regions of kDNA minicircles in the schizodemes of parental strain and clones, has been previously determined by Campos et al ${ }^{8}$ as shown in Table 1. No correlation has been detected between the percentile of similarity and susceptibility to chemotherapy. The clone with the lowest similarity (21SF-C5) has shown identical susceptibility ( $30 \%$ cure rate) to the parental strain (25\%). Apparently this clone is responsible for the lower responses to chemotherapy observed in mice infected with the parental strain, when compared to those infected with other components of the clonal population of the 21SF strain. This could suggest that phenotypic characteristics, such as the response to chemotherapy might differ even in the clones with a high degree of genetic similarity, evaluated by the schizodeme profiles.

Probably, this variation in susceptibility is responsible for failure of chemotherapy in a percentage of patients in endemic areas, even when infected with strains of T. cruzi that revealed a medium to high susceptibility.

The challenge for the chemotherapy of Chagas' disease is to detect drugs that could eliminate the more resistant clones present in the strains with high or medium susceptibility, as represented by biodeme Type II (T. cruzi II) and for the overall resistant clones of the biodeme Type III ( T. cruzi I) strains, as recently demonstrated by Camandaroba et al ${ }^{6}$.

\section{REFERENCES}

1. Andrade SG. Caracterização de cepas do Trypanosoma cruzi isoladas no Recôncavo Baiano (Contribuição ao estudo da patologia geral da doença de Chagas em nosso meio). Revista de Patologia Tropical 3: 65-121, 1974.

2. Andrade SG, Magalhães JB. Biodemes and zymodemes of Trypanosoma cruzi strains: correlations with clinical data and experimental pathology. Revista da Sociedade Brasileira de Medicina Tropical 30: 27-35, 1997.

3. Andrade SG, Magalhães JP, Pontes AL. Evaluation of chemotherapy with benznidazole and nifurtimox in mice infected with Trypanosoma cruzi strains of different types. Bulletin of the World Health Organization 63: 721-726, 1985.

4. Andrade SG, Magalhães JP, Pontes AL. Terapêutica da fase crônica da infecção experimental pelo Trypanosoma cruzi com o benznidazol e 0 nifurtimox. Revista da Sociedade Brasileira de Medicina Tropical 22: 113118, 1989

5. Andrade V, Brodskyn, C, Andrade SG. Correlation between isoenzyme patterns and biological behaviour of different strains of Trypanosoma cruzi. Transactions of the Royal Society of Tropical Medicine and Hygiene 76:796-799, 1983

6. Camandaroba ELP, Reis EAG, Gonçalves MS, Reis MG, Andrade SG. Trypanosoma cruzi: susceptibility to chemotherapy with benznidazole of clones isolated from the highly resistant Colombian strain. Revista da Sociedade Brasileira de Medicina Tropical 36: 201-209, 2003.

7. Campos RMF, Andrade SG. Characterization of subpopulations (clones and subclones) of the 21SF strain of Trypanosoma cruzi after long lasting maintenance in the laboratory. Memórias do Instituto Oswaldo Cruz 91:795800, 1996.

8. Campos RMF, Gonçalves MS, Reis EAG, Reis MG, Andrade SG. Comparative analysis by polymerase chain reaction amplified minicircles of kinetoplast DNA of a stable strain of Trypanosoma cruzi from São Felipe, Bahia, its clones and subclones: possibility of predominance of a principal clone in this area. Memórias do Instituto Oswaldo Cruz 94:23-29, 1999.

9. Laurent JP, Barnabé C, Quesney V, Noel S, Tibayrenc M. Impact of clonal evolution on the biological diversity of Trypanosoma cruzi. Parasitology 114: 213-218, 1997.

10. Marreto JPM, Andrade SG. Biochemical behavior of Trypanosoma cruzi strains isolated from mice submitted to specific chemotherapy. Revista da Sociedade Brasileira de Medicina Tropical 27: 209-215, 1994.

11. Miles MA, Apt W, Widner G, Povoa MM, Schofield CJ. Isozyme heterogeneity and numerical taxonomy of Trypanosoma cruzi stocks from Chile. Transactions of the Royal Society of Tropical Medicine and Hygiene 78: 526-535, 1984.

12. Miles MA, Lanham SM, Souza AA, Povoa M. Further enzymic characters of Trypanosoma cruzi in their evaluation for strain identification. Transactions of the Royal Society of Tropical Medicina and Hygiene 74: 221-237, 1980. 
13. Murta SMF, Romanha AJ. In vivo selection of a population of Trypanosoma cruzi and clones resistant to benznidazole. Parasitology 116: 165-171, 1998

14. Revollo S, Oury B, LaurentJP, Barnabé C, Quesney V, Carriere V, Noel S, Tibayrenc M. Trypanosoma cruzi : Impact of clonal evolution of the parasite on its biological and medical properties. Experimental Parasitology 89: 30-39, 1998.

15. Rocha Filho FD. Estudo comparativo de cepas do Trypanosoma cruzi de diferentes procedências ( aspectos antigênicos, morfológicos e histopatológicos) Tese de Mestrado. Universidade Federal da Bahia, Salvador, UFBA, 1979.
16. Solari A, Muñoz S, Venegas J, Wallace A, Aguilera X, Apt W, Breniere SF, Tibayrenc M. Characterization of Chilean, Bolivian, and Argentinean Trypanosoma cruzi populations by restriction endonuclease and isoenzyme analysis. Experimental Parasitology 75: 187-195, 1992.

17. Toledo MJ0, Bahia MT, Carneiro CM, Martins-Filho, OA, Tibayrenc M, Barnabé C, Tafuri WL, Lana M. Chemotherapy with benznidazole and itraconazole for mice infected with different Trypanosoma cruzi clonal genotypes. Antimicrobial Agents and Chemotherapy 47:223-230, 2003. 